\title{
Assessment of Urban Contamination by Sewage in Sediments from Ipojuca River in Caruaru City, Pernambuco, Brazil
}

\author{
Ana Flávia B. de Oliveira, ${ }^{a}$ Bruna R. S. Gomes, ${ }^{a}$ Rebeca S. França, ${ }^{b}$ Alex S. Moraes, ${ }^{a}$ \\ Giovana A. Bataglion ${ }^{\circledR b}$ and Jandyson M. Santos ${ }^{\circledR} * a$ \\ ${ }^{a}$ Departamento de Química, Universidade Federal Rural de Pernambuco (UFRPE), \\ 52171-900 Recife-PE, Brazil \\ ${ }^{b}$ Departamento de Química, Instituto de Ciências Exatas, \\ Universidade Federal do Amazonas (UFAM), 69077-000 Manaus-AM, Brazil
}

\begin{abstract}
The Ipojuca River is considered the third most polluted river in Brazil due to the intense anthropogenic activities in the surrounding urban areas. The most important effluent is sewage discharge, which is responsible for considerable contamination. Traditional analyses (infrared spectroscopy, organic matter (OM), elemental analysis and granulometry) and advanced analysis of sterols by liquid chromatography-tandem mass spectrometry (LC-MS/MS) were applied to evaluate the levels of urban contamination from sewage in 10 surface sediment samples from the Ipojuca River, in a stretch located in the Caruaru city, Pernambuco, Brazil. The results pointed to sandy sediments, rich in OM from anthropogenic sources (predominant). Eight different sterols were detected with a total concentration in a range between $<$ limit of quantification (LOQ) and $1,634.4 \mu \mathrm{g} \mathrm{g}^{-1}$. Coprostanol (fecal biomarker) was detected in high concentrations $\left(557.3 \mu \mathrm{g} \mathrm{g}^{-1}\right)$ in the sediment collected close to an open-air market (considered the largest in the world), making it the most contaminated in the region. Multivariate statistical analysis revealed areas tending towards contamination and that $90 \%$ of sediments were contaminated by sewage. These results can be considered useful for preventive and remedial actions toward promoting human health in this region.
\end{abstract}

Keywords: environmental biomarkers, organic matter, sterols, sediments, Ipojuca River

\section{Introduction}

Urban sewage represents one of the main sources of anthropogenic contamination in aquatic environments. It is constituted to be a complex mixture of organic matter $(\mathrm{OM})$, bacteria, oils, greases, detergents and metals, coming from facilities such as kitchens and bathrooms. ${ }^{1}$ In cities around rivers and lakes, especially in denselypopulated areas, the high volume of sewage generated daily and precariousness of basic sanitation results in major concerns for society. It is estimated that only about $45 \%$ of sewage is treated in Brazil, and another 55\% of untreated sewage is discharged directly into aquatic environments, which represents discharges of more than 5 billion $\mathrm{m}^{3}$ per year. ${ }^{2}$ This scenario is worrying because it can cause enrichment of aquatic nutrients (such as nitrogen and phosphorus), resulting in increased turbidity

*e-mail: jandyson.machado@ufrpe.br Editors handled this article: Eduardo Carasek and Maria Cristina Canela (Associated) and may impede the process of photosynthesis, leading to eutrophication of the environment. This also contributes to the transmission of bacterial and viral diseases, such as cholera and hepatitis A, especially for low-income populations who do not have access to treated water. ${ }^{3}$

Monitoring of aquatic environments is important for the preservation of water resources, guaranteeing quality and preventing the proliferation of diseases. Studies aiming to characterize the chemical composition of sedimentary OM have gained prominence over the years. $\mathrm{OM}$ is a heterogeneous mixture of microorganisms, plant and animal residues and its characterization may give information about the origin and composition related to the specific sedimentary OM of aquatic environments. ${ }^{4}$

Assessment of urban contamination by sewage in sedimentary OM is commonly carried out using sterol compound biomarker analysis, due to characteristics such as high specificity for the source, chemical stability and resistance to anaerobic degradation. Sterols are hydrophobic molecules associated with particulate materials remaining preserved over time. For this reason, sterols are used in the 
identification of anthropogenic discharges, such as urban sewage. ${ }^{5,6}$

In sediments without sewage contamination, biogenic OM can be identified by the presence of sterols, such as cholesterol and cholestanol (predominant in zooplankton and phytoplankton, respectively) and phytosterols (campesterol, stigmasterol and $\beta$-sitosterol, predominant in terrestrial plants). ${ }^{7-10}$ Moreover, in the sediments contaminated by sewage, it is possible to find a predominance of coprostanol and epicoprostanol. ${ }^{11}$

Coprostanol is a sterol produced by the human digestive tract through enzymatic reduction of cholesterol by anaerobic bacteria, which represents $40-60 \%$ of the total fecal sterols excreted by humans. ${ }^{6}{ }^{12}$ It is worth noting that human and animal feces have different profiles, the amount of coprostanol present in human feces is ten times higher than in excrement from cattle and other vertebrates, which increases its specificity in OM sediments. ${ }^{13}$ Epicoprostanol is an isomer of coprostanol found in sewage treatment systems due to the process of aerobic digestion of sludge, presenting high concentrations in anoxic environments. Therefore, it can be used to determine the level of treatment that was applied to the effluent. ${ }^{12}$

The identification of fecal contamination from absolute values of coprostanol alone is not recommended given the possibility of in situ productions. ${ }^{13,14}$ To increase reliability, previous studies ${ }^{5-11,13,15,16}$ have identified diagnostic ratios of some sterols that can be used as an aid tool in the determination of fecal contamination. The most common ratios used for the assessment of sewage contamination are: (coprostanol/(coprostanol + cholestanol), coprostanol/ cholesterol and epicoprostanol/coprostanol.

The detection and quantification of sterols have traditionally been done through gas chromatography with flame ionization or mass spectrometry. ${ }^{17}$ However, the low volatility and high molecular weight of sterols makes it necessary to apply methods demanding laborious sample pre-treatment, which prolongs the analysis time. ${ }^{14}$ Alternatively, liquid chromatography-tandem mass spectrometry (LC-MS/MS) makes it possible to separate and identify compounds of greater polarity more quickly, based on the interaction of each analyte with the stationary phase contained in a chromatographic column, decreasing sterol analysis time. ${ }^{18}$

To the best of our knowledge, there is no data about the distribution of sterols in sediments of Ipojuca River that has aimed to investigate the level of fecal contamination. Thus, the chosen objective of this study was to characterize OM sediments from superficial samples of Ipojuca River applying traditional analyses (infrared spectroscopy, organic matter, elemental analysis and granulometry).
Furthermore, the study included an advanced analysis for sterol quantification (LC-MS/MS), aiming to evaluate contamination by sewage of a specific urban area. We also present a comprehensive data interpretation from a geochemical point of view using multivariate statistical analysis.

\section{Experimental}

\section{Description of study area}

The study area corresponds to the hydrographic basin of the Ipojuca River, located in the Northeast region of Brazil (state of Pernambuco), with source in the interior of the state (municipality of Arcoverde) and mouth on the south coast (municipality of Ipojuca), ending in Atlantic Ocean. Over its $320 \mathrm{~km}$ in length and $3,435.34 \mathrm{~km}^{2}$ of total area, the river supplies 12 municipalities, including Caruaru city, which is considered the most populous in the interior of Pernambuco with 365,278 habitants. Caruaru is responsible for $2.43 \%$ of the gross domestic product of the state and is one of the strongest economic and cultural centers in the area. The regional climate is tropical semiarid, with a mean annual temperature of $22.5^{\circ} \mathrm{C}$ and little rainfall throughout the year. ${ }^{19}$

The Ipojuca River passes through about $30 \mathrm{~km}$ of the urban area of the municipality of Caruaru and serves as an incentive to tourism, with activities including rafts, river baths and fishing, for the communities which live along the edge of the river. The unregulated disposal of garbage and sewage in nature along the course of the river, resulting from the high population, intense anthropogenic activities and presence of trade on its banks, has caused deterioration of the river. Recently, the Ipojuca River was reported to be the $3^{\text {rd }}$ most polluted river in Brazil with $90 \%$ of sewage in its composition, poor marine life and significant levels of environmental degradation, caused mainly by domestic, industrial and agribusiness effluents. ${ }^{19}$ This situation indicates that there is a need to produce a study evaluating at the molecular level the degree of this contamination, which has motivated the study presented here.

\section{Sample collection e pretreatment}

A total of 10 surface sediment samples $(0-10 \mathrm{~cm})$ were collected along $7 \mathrm{~km}$ of length of the Ipojuca River (Figure 1), in a stretch located in the municipality of Caruaru, in September 2018. The samples were collected in regions of low and high population occupation, as well as regions of accentuated discharge of sewage, garbage and with signs of anthropogenic impact. 


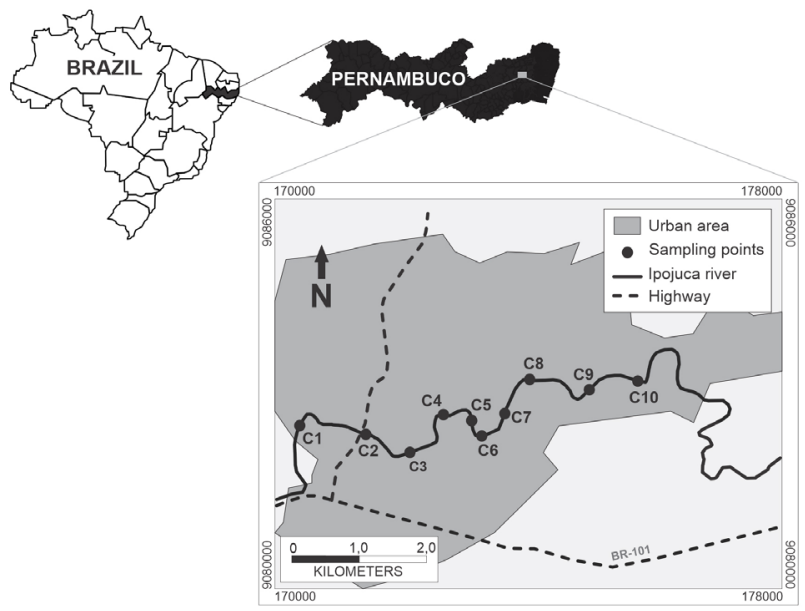

Figure 1. Study area and sampling stations in the Ipojuca River located in the urban area of the Caruaru city. Sampling sites: C1 ( $8^{\circ} 17^{\prime} 17^{\prime \prime} \mathrm{S}$; $\left.35^{\circ} 59^{\prime} 35^{\prime \prime} \mathrm{W}\right)$; C2 ( $8^{\circ} 16^{\prime} 58^{\prime \prime} \mathrm{S}$; $\left.35^{\circ} 58^{\prime} 54^{\prime \prime} \mathrm{W}\right)$; C 3 ( $8^{\circ} 17^{\prime} 37^{\prime \prime} \mathrm{S}$; $\left.35^{\circ} 58^{\prime} 44^{\prime \prime} \mathrm{W}\right)$; C4 ( $\left.8^{\circ} 17^{\prime} 17^{\prime \prime} \mathrm{S} ; 35^{\circ} 58^{\prime} 27^{\prime \prime} \mathrm{W}\right)$; C5 ( $8^{\circ} 17^{\prime} 18^{\prime \prime} \mathrm{S}$; $\left.35^{\circ} 58^{\prime} 10^{\prime \prime} \mathrm{W}\right)$; C6 ( $8^{\circ} 17^{\prime} 28^{\prime \prime} \mathrm{S}$; $\left.35^{\circ} 58^{\prime} 06^{\prime \prime} \mathrm{W}\right)$; C7 ( $8^{\circ} 17^{\prime} 13^{\prime \prime} \mathrm{S}$;

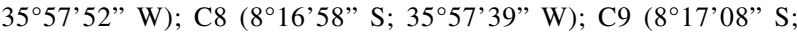
$\left.35^{\circ} 57^{\prime} 16^{\prime \prime} \mathrm{W}\right)$; C10 ( $\left.8^{\circ} 16^{\prime} 59^{\prime \prime} \mathrm{S} ; 35^{\circ} 56^{\prime} 48^{\prime \prime} \mathrm{W}\right)$.

About $300 \mathrm{~g}$ of sediments were collected in each sample point with a Van Veen dredge and stored in glass bottles (previously washed with Extran 5\% solution and deionized water, respectively). The samples were transported at low temperature $\left(4^{\circ} \mathrm{C}\right)$ and taken to the laboratory, then were dried in a circulation oven at $60^{\circ} \mathrm{C}$ for $48 \mathrm{~h}$, macerated with the aid of a pistil and mortar, sieved $(<2 \mathrm{~mm})$ and stored at room temperature.

\section{Chemicals and reagents}

The high-performance liquid chromatography (HPLC)-grade methanol and dichloromethane were purchased from Tedia (Rio de Janeiro, Brazil). Coprostanol ( $3 \beta, 5 \beta$-cholestan-3-ol), epicoprostanol ( $3 \alpha, 5 \beta$-cholestan3 -ol), cholesterol (3 $\beta$-cholest-5-en-3-ol), cholestanol

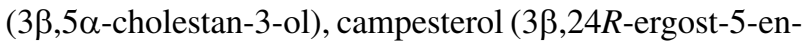
3 -ol), stigmasterol $(3 \beta, 22 E)$-stigmasta-5,22-dien-3-ol), $\beta$-sitosterol (24-ethycholest-5-en-3 $\beta$-ol), stigmastanol (3 $\beta, 5 \alpha$-stigmastan-3-ol), brassicasterol $((3 \beta, 22 E)$-ergosta5,22-dien-3-ol), ergosterol ((3ß,22E)-ergosta-5,7,22-trien3 -ol) and cholesterol- $d_{6}$ were obtained from SigmaAldrich (St. Louis, USA). The cholesterol- $d_{6}$ was used as a deuterated internal standard (IS) for quantification of all compounds based on their similar structure. Stock solutions containing the individual sterols $\left(1.0 \mathrm{mg} \mathrm{mL}^{-1}\right)$ were prepared with dichloromethane. Working standard solutions at $2.0 \mu \mathrm{g} \mathrm{mL}^{-1}$ containing all sterols were prepared by diluting the stock solutions in methanol. The $2.0 \mu \mathrm{g} \mathrm{mL}^{-1}$ solution was used to prepare the analytical curves in the concentration range from 10.0 to
$1000.0 \mathrm{ng} \mathrm{mL}^{-1}$ in nine levels of each analyte containing $500.0 \mathrm{ng} \mathrm{mL}^{-1}$ of IS. ${ }^{20}$

\section{Characterization of sediments by classical analyses}

The first group of techniques used refers to the most classical analyses (defined as the most common analyses used in characterization of soils and sediments), which comprises: infrared spectroscopy, gravimetry to determine the OM content, elemental analysis and granulometry.

The sediments were analyzed in the medium region by infrared spectroscopy (400-4000 $\left.\mathrm{cm}^{-1}\right)$ using an IR TRACER-100 with Fourier transform (Shimadzu Co., Japan) with $4 \mathrm{~cm}^{-1}$ of acquisition resolution. For analysis, $1 \mathrm{mg}$ of sediment was macerated with $\mathrm{KBr}$ using grail and agate pistil and then subjected to a hydraulic press. The data processing was done by normalization by sup standard. The determination of OM was performed by gravimetry after calcination for $6 \mathrm{~h}$ at a temperature of approximately $750{ }^{\circ} \mathrm{C}$, as described in a previous methodology. ${ }^{21}$

For elemental analysis, $1 \mathrm{~g}$ of each sample was decarbonated using a hydrochloric acid (Vetec, Rio de Janeiro, Brazil) solution at $0.1 \mathrm{~mol} \mathrm{~L}^{-1}$. The process was repeated with deionized water to remove excess acid and with posterior drying at $60^{\circ} \mathrm{C}$, for the elimination of water. Decarbonated samples were analyzed using a CHN628 (LECO Co., USA) with software CHN628 version 1.30, previously calibrated with an ethylenediaminetetraacetic acid (EDTA) standard $(41.0 \% \mathrm{C}, 5.5 \% \mathrm{H}$ and $9.5 \% \mathrm{~N})$. The analysis was done by weighing approximately $50 \mathrm{mg}$ in aluminum foil.

Granulometric analyses were carried by grain size distributions in two stages: the first allowed separation of fine fractions (silt + clay) from the sand fraction, through wet sieving of the samples $(0.063 \mathrm{~mm})$ and the second stage separate the fine fraction into silt and clay, through pipetting technique using the Stokes principle. As a final result, fractions were estimated as silt, sand and clay. ${ }^{22}$

\section{Extraction and fractionation of sterols}

The extraction and fractionation of organic compounds were carried out following the method described by Rau et al. ${ }^{23}$ Briefly, the extraction was done using $5 \mathrm{~g}$ of dry sediment added to the activated copper and cholesterol- $d_{6}$ (IS) at a concentration of $2 \mu \mathrm{g} \mathrm{g}^{-1}$. Then, $15 \mathrm{~mL}$ of a mixture of dichloromethane and methanol $(2: 1, \mathrm{v} / \mathrm{v})$ was added and subjected to vortex and ultrasonic bath for $30 \mathrm{~min}$. The process was carried out three times and the organic extracts were combined. The final extract was subjected to rotary 
evaporation at $45 \pm 5{ }^{\circ} \mathrm{C}$, until complete the elimination of solvent.

The extract was subjected to fractionation performed by open column chromatography using $5 \mathrm{~g}$ of silica gel and $1 \mathrm{~g}$ of alumina, both previously dried at $200{ }^{\circ} \mathrm{C}$ and disabled with $5 \%$ water. In total, four fractions of the organic extract were obtained: fraction one referring to aliphatic hydrocarbons, fraction two referring to aromatic hydrocarbons, fraction three referring to alcohols and sterols and fraction four regarding the fatty acids. The fraction of sterols was re-dissolved in dichloromethane, diluted in methanol and transferred to vial-type flasks for analysis by LC-MS/MS.

\section{Determination of sterols by LC-MS/MS}

Determination of ten sterols (coprostanol, epicoprostanol, cholesterol, cholestanol, campesterol, stigmasterol, $\beta$-sitosterol, stigmastanol, brassicasterol and ergosterol) in sedimentary OM extracts was performed using a liquid chromatography 1200 Series from Agilent (Santa Clara, USA) coupled to a QTrap mass spectrometer model API 4000 (Applied Biosystems, Darmstadt, Germany) equipped with an atmospheric pressure chemical ionization (APCI), which operated in the positive ion mode acquisition.

The validation of the method presented in this study was carried out by obtaining the main analytical parameters, detailed previously by Bataglion et al. ${ }^{8}$ as instrumental and chromatographic conditions (Table S1, Supplementary Information (SI) section). The chromatographic separation was performed on a reverse phase column Shimpack XR-ODS octadecyl-C18 (column: $150 \mathrm{~mm}$; inside diameter: $2.0 \mathrm{~mm}$; particle size: $2.2 \mu \mathrm{m}$ ) (Shimadzu, Kyoto, Japan). Chromatographic separation was carried out using methanol and water as mobile phases A and B, respectively. The gradient elution was as follow: 0-2 $\mathrm{min}$ (90\% methanol), 2-8 min (100\% methanol), 8-9 min (90\% methanol), $9-10 \mathrm{~min}$ (90\% methanol), at a flow rate of $0.6 \mathrm{~mL} \mathrm{~min}^{-1}$. The temperature of the injector and chromatographic oven were 10 and $30{ }^{\circ} \mathrm{C}$, respectively, and the injection volume was $10 \mu \mathrm{L}$. APCI source was operated with the parameters: corona current at $4.0 \mu \mathrm{A}$, the temperature at $450{ }^{\circ} \mathrm{C}$, curtain gas at 10 and ionization gas of 1 of 30 (arb).

Sterols detection was performed using selected reaction monitoring (SRM) with two product ions of each precursor selected $\left[\mathrm{M}+\mathrm{H}-\mathrm{H}_{2} \mathrm{O}\right]^{+}$, while quantification was performed using IS, where calibration curves were run in triplicate in the concentration range of 10 to $1000 \mathrm{ng} \mathrm{mL}^{-1}$ for analytes and $500 \mathrm{ng} \mathrm{mL}^{-1}$ for IS. ${ }^{20}$

\section{Multivariate statistical analysis}

To find trends and similarities between samples and variables, multivariate statistical analyses were performed using data obtained in the classical analyses (OM, total organic carbon (TOC), H, total nitrogen (TN), TOC/TN, $\mathrm{H} / \mathrm{C}$, sand, silt, clay and silt + clay, in percentage) and sterols determination (coprostanol, cholesterol, epicoprostanol, cholestanol), as well as, their respective sterol ratios: coprostanol/cholesterol, (coprostanol/ (coprostanol+cholestanol)) and epicoprostanol/ coprostanol)). Data that is below the limit of quantification or could not be calculated has been replaced by zero.

\section{Results and Discussion}

\section{Classical analyses}

In the infrared spectrum (Figure S1, Supplementary Information (SI) section) bands associated with quartz, clay materials and the chemical composition of sedimentary OM were found. In all samples, a strong and wide band was observed at $3439 \mathrm{~cm}^{-1}$; this was more intense in $\mathrm{C} 1$ sediment, attributed to $\mathrm{O}-\mathrm{H}$ stretching of phenolic and carboxylate groups and/or clay (in particular, $\mathrm{Al}-\mathrm{OH}$ and $\mathrm{Si}-\mathrm{OH}$ ) and/or water molecule and/or $\mathrm{N}-\mathrm{H}$ stretching of secondary amines. The band at $1645 \mathrm{~cm}^{-1}$, more evident in the $\mathrm{C} 10$ sediment, refers to the aromatic $\mathrm{C}=\mathrm{C}$ stretching, while the bands at $1436 \mathrm{~cm}^{-1}$ may be associated with the aromatic $\mathrm{C}-\mathrm{H}$ deformation band, $\mathrm{N}=\mathrm{O}$ stretching, $\mathrm{O}-\mathrm{H}$ stretching of phenols and/or $\mathrm{CH}_{2}$ and $\mathrm{CH}_{3}$ deformations groups. These functional groups are characteristic for sedimentary OM due to humic acids composition, which is constituted of macromolecules resulting from the decomposition of OM. ${ }^{24}$

All samples presented peaks at $3616 \mathrm{~cm}^{-1}$, attributed to mineral impurities, ${ }^{24}$ while the strong peak at $3701 \mathrm{~cm}^{-1}$ corresponds to $\mathrm{O}-\mathrm{Al}-\mathrm{OH}$ stretching due to the presence of kaolinite, confirmed through $\mathrm{O}-\mathrm{Al}-\mathrm{OH}$ and $\mathrm{Si}-\mathrm{O}$ vibrations presents from 1024 to $400 \mathrm{~cm}^{-1} .^{25}$ The low transmittance peaks at 2922 and $2855 \mathrm{~cm}^{-1}$, higher in the $\mathrm{C} 10$ sediment, are attributed to $-\mathrm{CH}_{3}$ and $-\mathrm{CH}_{2}$ stretching vibrations, respectively, which suggests the possibility of contamination by hydrocarbons in this region. ${ }^{24,26}$

The peak at $1016 \mathrm{~cm}^{-1}$ present in all samples can be associated with angular deformation $\mathrm{Al}-\mathrm{OH}$ and axial deformation $\mathrm{Si}-\mathrm{O}$ from silicates (mainly illite and kaolinite), ${ }^{24}$ and an additional band at $1095 \mathrm{~cm}^{-1}$ corresponding to $\mathrm{C}-\mathrm{O}$ stretching of humic acid polysaccharides and/or silicate impurities. The peaks from 400 to $1000 \mathrm{~cm}^{-1}$ are attributed to the presence of quartz, 
such as quartz doublet peak $\left(780 \mathrm{~cm}^{-1}\right)$, $\mathrm{Si}-\mathrm{O}$ vibration of silicate materials $\left(693 \mathrm{~cm}^{-1}\right), \mathrm{Fe} / \mathrm{Al}-\mathrm{O}-\mathrm{Si}$ deformation of sheet silicates (as feldspars and micas) $\left(542 \mathrm{~cm}^{-1}\right)$ and $\mathrm{Si}-\mathrm{O}-\mathrm{Si}$ vibration of sheet silicates $\left(468 \mathrm{~cm}^{-1}\right){ }^{26}$

The results of $\mathrm{OM}$, granulometry and elemental analysis are summarized in Table 1. We found the highest fraction for sand (from 52 to $96.9 \%$ ) considering all samples, indicating that the study region has been subjected to considerable hydrodynamic action, which may be associated with the high flow and narrowing of the river at this point. These factors are responsible for a lower deposit of fine sediments, due to the strong action of the river currents. OM contents varied from 1.48 to $10.53 \%$, indicating that all sediments are rich in $\mathrm{OM}(>0.5 \%) .{ }^{27}$ Previous studies ${ }^{28}$ suggest that $\mathrm{OM}$ is directly associated with sediment granulometry, where fine particles provide a larger surface area, generating greater accumulation of $\mathrm{OM}$. Considering that samples $\mathrm{C} 1, \mathrm{C} 4$ and $\mathrm{C} 10$ showed the highest values of $\mathrm{OM}$ and fine particles, the linear correlations were performed; a moderate correlation $\left(\mathrm{R}^{2}=0.44\right)$ was found for these three samples (Table S2, SI section).

TOC is a fundamental parameter for characterizing different sources of sedimentary OM and represents the fraction of $\mathrm{OM}$ that escaped remineralization during sedimentation. ${ }^{29}$ The TOC percentages obtained varied widely (from 0.21 to $3.53 \%$ ) indicating different $\mathrm{OM}$ inputs, which could have been caused by structural differences in local vegetation, resulting in greater amounts of biomass or by the amount of roots in the soil. ${ }^{30}$ All samples presented $\mathrm{TN}$ below $1 \%$, indicating that regions are subjected to intense reducing conditions, resulting in a denitrification process. ${ }^{31} \mathrm{TOC} / \mathrm{TN}$ ratio was also determined to differentiate $\mathrm{OM}$ derived from aquatic plants (from 4 to $10)$ and terrestrial plants $(>20) .{ }^{29} \mathrm{The} \mathrm{TOC} / \mathrm{TN}$ ranges were identified from 4.11 to 10.11 , which indicates that $\mathrm{OM}$ of all sediments is mostly from aquatics sources containing a low concentration of cellulose and a high concentration of proteins. ${ }^{32}$ This is valid when there is a linear correlation between TOC and TN (Table S2), as was found for our data when we plotted the linear graph where $\mathrm{R}^{2}=0.99$ was obtained. Considering that fecal materials have a significant influence on TOC level, which represented about $50 \%$ of the $\mathrm{OM}$, a linear correlation $\left(\mathrm{R}^{2}=0.84\right)$ was found between TOC and OM, indicating possible sewage contamination in the sediments (see Table S2). ${ }^{30,33}$ The highest value of TOC/TN was found in $\mathrm{C} 4$ sediment; these high TOC and TN values suggest sediment contamination by urban sewage, due to the entry of anthropogenic carbon. ${ }^{34}$

Considering that the $\mathrm{H} / \mathrm{C}$ ratio estimates the degree of aromaticity of sedimentary $\mathrm{OM}$, the $\mathrm{C} 2$ and $\mathrm{C} 7$ samples are the most aromatic $(\mathrm{H} / \mathrm{C}>1)$. This is due to $\mathrm{OM}$ resulting from the decomposition of terrestrial plants and microorganisms, originating from the degradation of lignin, carbohydrates and proteins (paraffinic compounds), thus providing a decrease in the $\mathrm{H} / \mathrm{C}$ ratio. ${ }^{35}$

In particular, the traditional common results for sediments as listed in Table 1 provide an interesting perspective on the $\mathrm{C} 4$ sample. $\mathrm{C} 4$ has the highest levels of OM, TOC, TN and TOC/TN, compared with the other samples, which suggests that the sedimentary OM of the C4 point is formed by a strong substantial contribution of anthropogenic OM; this needed to be confirmed by LC-MS/MS analysis of sterols.

\section{Absolute concentrations of sterol biomarkers}

The absolute sterol concentrations are summarized in Table 2. We detected eight sterols with a total concentration in a range between 4.2 and $1,634.4 \mu \mathrm{g} \mathrm{g}^{-1}$. The variability of fecal (coprostanol and epicoprostanol) and biogenic

Table 1. Results of organic matter, elemental analysis and granulometry of surface sediments from Ipojuca River, Pernambuco, Brazil

\begin{tabular}{lcccccccc}
\hline Sampling site & OM / \% & Sand $/ \%$ & Silt + clay $/ \%$ & TOC / $\%$ & TN / \% & TOC/TN & H / \% & H/C \\
\hline C1 & $5.31 \pm 0.25$ & 55.8 & 38.1 & 1.06 & 0.12 & 8.91 & 0.16 & 1.79 \\
C2 & $2.77 \pm 0.15$ & 86.9 & 10.5 & 0.91 & 0.09 & 9.92 & 0.04 & 0.52 \\
C3 & $3.99 \pm 0.22$ & 69.7 & 25.6 & 0.92 & 0.10 & 9.69 & 0.08 & 1.01 \\
C4 & $10.53 \pm 0.50$ & 52.0 & 31.6 & 3.53 & 0.35 & 10.11 & 0.58 & 1.98 \\
C5 & $2.70 \pm 0.05$ & 86.5 & 10.7 & 0.43 & 0.07 & 5.82 & 0.09 & 2.44 \\
C6 & $1.48 \pm 0.10$ & 91.8 & 6.8 & 0.21 & 0.05 & 4.11 & $<$ LOD & NC \\
C7 & $5.36 \pm 0.52$ & 90.6 & 3.6 & 0.32 & 0.06 & 5.47 & 0.02 & 0.80 \\
C8 & $2.37 \pm 0.23$ & 94.1 & 4.1 & 0.39 & 0.07 & 5.68 & 0.10 & 3.23 \\
C9 & $2.96 \pm 0.16$ & 96.9 & 1.6 & 0.39 & 0.05 & 7.46 & 0.33 & 10.34 \\
C10 & $6.94 \pm 0.62$ & 72.1 & 26.3 & 2.07 & 0.21 & 9.97 & 0.24 & 1.36 \\
\hline
\end{tabular}

OM: organic matter; TOC: total organic carbon; TN: total nitrogen; H: hydrogen; LOD: limit of detection; NC: not calculated (one or more components of the ratio are below the limit of quantification). 
Table 2. Absolute concentrations of sterols and their diagnostic ratios for sediments from Ipojuca River, Pernambuco, Brazil

\begin{tabular}{|c|c|c|c|c|c|c|c|c|c|c|c|c|c|c|c|}
\hline Sample & $\begin{array}{c}\text { Cop / } \\
\left(\mu \mathrm{g} \mathrm{g}^{-1}\right)\end{array}$ & $\begin{array}{l}\text { Epico / } \\
\left(\mu \mathrm{g} \mathrm{g}^{-1}\right)\end{array}$ & $\begin{array}{l}\text { Cholr / } \\
\left(\mu \mathrm{g} \mathrm{g}^{-1}\right)\end{array}$ & $\begin{array}{l}\text { Choln / } \\
\left(\mu \mathrm{g} \mathrm{g}^{-1}\right)\end{array}$ & $\begin{array}{l}\text { Camp / } \\
\left(\mu \mathrm{g} \mathrm{g}^{-1}\right)\end{array}$ & $\begin{array}{c}\text { Stig / } \\
\left(\mu \mathrm{g} \mathrm{g}^{-1}\right)\end{array}$ & $\begin{array}{l}\beta-\text { Sitr / } \\
\left(\mu \mathrm{g} \mathrm{g}^{-1}\right)\end{array}$ & $\begin{array}{c}\text { Sitn / } \\
\left(\mu \mathrm{g} \mathrm{g}^{-1}\right)\end{array}$ & $\begin{array}{c}\text { Sterols / } \\
\left(\mu \mathrm{g} \mathrm{g}^{-1}\right)\end{array}$ & $\mathrm{R} 1 / \%$ & $\mathrm{R} 2$ & R3 & $\mathrm{R} 4$ & R5 & R6 \\
\hline$\overline{\mathrm{C} 1}$ & $<\mathrm{LOQ}$ & $<$ LOQ & $<\mathrm{LOQ}$ & $<\mathrm{LOQ}$ & 0.9 & 1.0 & 2.1 & 0.2 & 4.2 & $\mathrm{NC}$ & $\mathrm{NC}$ & $\mathrm{NC}$ & $\mathrm{NC}$ & $\mathrm{NC}$ & $\mathrm{NC}$ \\
\hline $\mathrm{C} 2$ & 69.7 & 5.5 & 8.8 & 10.9 & 2.8 & 1.6 & 4.5 & 10.9 & 114.7 & 61 & 0.86 & 0.87 & 7.88 & 6.40 & 0.08 \\
\hline $\mathrm{C} 3$ & 17.7 & 2.0 & 2.1 & 4.4 & 1.8 & 1.4 & 5.0 & 3.0 & 37.4 & 47 & 0.80 & 0.82 & 8.31 & 4.00 & 0.11 \\
\hline $\mathrm{C} 4$ & 557.3 & 125.1 & 182.9 & 274.7 & 78.9 & 29.8 & 133.1 & 252.5 & $1,634.4$ & 34 & 0.67 & 0.71 & 3.05 & 2.03 & 0.22 \\
\hline C5 & 37.5 & 3.3 & 4.6 & 8.2 & 1.5 & 0.6 & 2.4 & 6.6 & 64.7 & 58 & 0.82 & 0.83 & 8.12 & 4.60 & 0.09 \\
\hline C6 & 49.6 & 2.7 & 7.8 & 5.1 & 2.1 & 0.9 & 3.3 & 7.5 & 79.0 & 63 & 0.91 & 0.91 & 6.35 & 9.69 & 0.05 \\
\hline $\mathrm{C} 7$ & 289.8 & 26.9 & 37.0 & 52.7 & 11.0 & 4.7 & 17.6 & 56.8 & 496.6 & 58 & 0.85 & 0.86 & 7.83 & 5.50 & 0.09 \\
\hline $\mathrm{C} 8$ & 98.2 & 7.3 & 13.4 & 11.1 & 2.9 & 1.2 & 5.5 & 15.3 & 154.8 & 63 & 0.90 & 0.90 & 7.35 & 8.86 & 0.07 \\
\hline C9 & 38.1 & 2.7 & 7.3 & 3.9 & 1.4 & 0.6 & 3.0 & 5.8 & 62.7 & 61 & 0.91 & 0.91 & 5.20 & 9.72 & 0.07 \\
\hline $\mathrm{C} 10$ & 199.1 & 14.2 & 29.9 & 24.6 & 6.7 & 2.9 & 12.7 & 31.5 & 321.4 & 62 & 0.89 & 0.90 & 6.67 & 8.08 & 0.07 \\
\hline
\end{tabular}

Cop: coprostanol; Epico: epicoprostanol; Cholr: cholesterol; Choln: cholestanol; Camp: campesterol; Stig: stigmasterol; $\beta$-Sitr: $\beta$-sitosterol; Sitn: sitostanol; R1: coprostanol/total sterols; R2: coprostanol/(coprostanol + cholestanol); R3: coprostanol + epicoprostanol/(coprostanol + epicoprostanol + cholestanol); R4: coprostanol/cholesterol; R5: coprostanol/cholestanol; R6: epicoprostanol/coprostanol; NC: not calculated (one or more components of the ratio are below the limit of quantification); LOQ: limit of quantification.

sterols (as $\beta$-sitosterol and campesterol) found suggests that the geographical area under study receives a strong contribution of OM from different sources.

The lowest concentration of total sterols was found in the $\mathrm{C} 1$ sediment. Concentrations of cholesterol, epicoprostanol, coprostanol and cholestanol in $\mathrm{C} 1$ were also found below the limit of quantification. In addition, the predominance of $\beta$-sitosterol (>50\%) suggests a strong contribution of terrestrial $\mathrm{OM}$, possibly due to the influence of terrestrial plants in the region. ${ }^{10,36}$ Thus, the $\mathrm{C} 1$ region can be considered preserved and free of contamination, which may be explained due to the presence of forests and vegetation on its bank river, as well as being in a region with low population occupation.

In contrast, coprostanol was the predominant sterol in $90 \%$ of the sediments (< limit of quantification (LOQ)-557.3 $\mu \mathrm{g} \mathrm{g}^{-1}$ ). This is the sterol most commonly used to indicate the fecal origin of $\mathrm{OM}$ in aquatic environments. Considering that limits higher than $0.5 \mu \mathrm{g} \mathrm{g}^{-1}$ indicate highly contaminated sediments, all sediments from $\mathrm{C} 2$ to $\mathrm{C} 10$ are subject to a high amount of sewage. ${ }^{10,15}$ This stretch of the river represents the most populous portion of the city, including families living along the edge of the river, with precarious structures and without adequate basic sanitation. In the region, there also are no sewage treatment plants and the discharge of untreated sewage can be considered as the source of fecal sterols. ${ }^{13}$

Note that the highest values of total sterols and coprostanol occurred in the $\mathrm{C} 4$, where also were found the highest values of $\mathrm{OM}(10.53 \%), \mathrm{TOC}(3.53 \%), \mathrm{TN}(0.35 \%)$ and TOC/TN (10.11), as previously mentioned. To the best of our knowledge, when our results are compared with studies of other Brazilian aquatic environments, the coprostanol concentration found in $\mathrm{C} 4$ appears to be the highest ever recorded, as shown in Table 3. For an international comparison, the concentration of $\mathrm{C} 4$ was the highest in the most of the studies recorded and only slightly lower than what has been recorded in the contaminated areas of Yucatan Cenotes, Mexico ${ }^{37}$ and Rio

Table 3. The highest concentration of coprostanol found in sediments from different aquatic environments registered in the world

\begin{tabular}{|c|c|c|c|}
\hline Field of study & Reference & Environment & $\begin{array}{c}\text { Coprostanol / } \\
\left(\mu \mathrm{g} \mathrm{g}^{-1}\right)\end{array}$ \\
\hline $\begin{array}{l}\text { Yucatan Cenotes, } \\
\text { Mexico }\end{array}$ & $\begin{array}{c}\text { Arcega-Cabrera } \\
\text { et al. } .^{37}\end{array}$ & underground & $1,690.0$ \\
\hline $\begin{array}{l}\text { Rio de la Plata, } \\
\text { Argentina }\end{array}$ & Speranza et al. ${ }^{36}$ & river & 708.0 \\
\hline Our study & - & river & 557.3 \\
\hline $\begin{array}{l}\text { Iguaçu River, PR, } \\
\text { Brazil }\end{array}$ & Puerari et al. ${ }^{38}$ & river & 375.0 \\
\hline $\begin{array}{l}\text { Manitoba, } \\
\text { Canada }\end{array}$ & Tse $e t a l .^{7}$ & lake & 252.3 \\
\hline $\begin{array}{l}\text { Xiaoqing River, } \\
\text { China }\end{array}$ & He et al..$^{9}$ & river & 63.2 \\
\hline $\begin{array}{l}\text { Santa Monica } \\
\text { Bay, USA }\end{array}$ & Venkatesan et al. ${ }^{39}$ & sea & 46.0 \\
\hline $\begin{array}{l}\text { Vitoria Bay, ES, } \\
\text { Brazil }\end{array}$ & Hadlich et al..$^{40}$ & sea & 13.1 \\
\hline $\begin{array}{l}\text { Quarenta Stream, } \\
\text { AM, Brazil }\end{array}$ & de Melo et al..$^{20}$ & river & 12.8 \\
\hline $\begin{array}{l}\text { Itajaí-Açú, SC, } \\
\text { Brazil }\end{array}$ & Frena et al. ${ }^{6}$ & estuary & 8.9 \\
\hline $\begin{array}{l}\text { Santos Bay, SP, } \\
\text { Brazil }\end{array}$ & Martins et al..$^{12}$ & sea & 8.5 \\
\hline $\begin{array}{l}\text { Cienfuegos Bay, } \\
\text { Cuba }\end{array}$ & Tolosa et al. ${ }^{15}$ & sea & 5.4 \\
\hline $\begin{array}{l}\text { Danube River, } \\
\text { Serbia }\end{array}$ & $\begin{array}{l}\text { Matić Bujagić } \\
\text { et al. }{ }^{13}\end{array}$ & sea & 1.9 \\
\hline $\begin{array}{l}\text { São Francisco } \\
\text { River, Brazil }\end{array}$ & Frena et al..$^{41}$ & river & 0.1 \\
\hline
\end{tabular}


de la Plata, Argentina. ${ }^{36}$ The results found in our study are extremely worrisome and suggest that the $\mathrm{C} 4$ sediment region in particular is the most critical, receiving directly or indirectly high sewage discharges possibly from activities of open-market of Caruaru and the high urban occupation in the region.

Cholestanol and cholesterol may suggest intense aquatic productivity that can result in the presence of phytoplankton, such as diatoms (autochthonous OM). ${ }^{13}$ Due to the high concentration of fecal sterols, however, such as coprostanol and epicoprostanol, we cannot consider that cholesterol comes exclusively from aquatic sources. ${ }^{41}$ Sewage inputs can lead to eutrophication of aquatic environments and also increase the production of cholesterol, cholestanol and phytosterols. We found a linear correlation between fecal sterols (coprostanol and epicoprostanol) with cholesterol, cholestanol and phytosterols (campesterol, stigmasterol and $\beta$-sitosterol), with values of $\mathrm{R}^{2}$ above 0.8 (Table S2), which confirm that inputs of domestic sewage are also responsible for the formation of sedimentary OM, indicating anthropogenic inputs in the aquatic environment. We also evaluated the correlations between TOC and some individual sterol concentrations, shown in Table S2. The results showed moderate linear correlations $\left(\mathrm{R}^{2}\right.$ from 0.59 to 0.73 ), which indicates that sterols contribute in the same proportion to the total organic content of the sediments, corroborating the presence of source differences (biogenic and anthropogenic). 5,20

\section{Sterol ratios}

The individual assessment of contamination by coprostanol concentration needs to be carried out with caution because the results depend on the amount of sterols analyzed, requiring the application of diagnostic ratios to ensure greater reliability to the interpretation. ${ }^{20}$ Thus, a set of six diagnostic sterol ratios (Table 2) were calculated to determine anthropogenic contamination by sewage and to identify the sources of OM in the sediments. ${ }^{13,14}$ No ratios were calculated for the $\mathrm{C} 1$ sample because some sterol concentrations were below the limit of quantification.

The R1 ratio (coprostanol/total sterols $(\%)$ ) enables assessment of the presence of fecal sterol in sediments; percentages greater than $5 \%$ suggest severe contamination. ${ }^{15,40}$ Considering that coprostanol was the predominant sterol in the most of samples, most of which had values higher than $5 \%$, the result represents a strong indication that the full study region is severely contaminated by sewage.

$\mathrm{R} 2$ ratio (coprostanol/(coprostanol + cholestanol)) was used to indicate the presence of sewage in aquatic environments (reference range: $0.5<\mathrm{R} 2<1.0$ ), considering that reduction of cholesterol in the human body mainly produces coprostanol, while in the environment it produces mostly cholestanol. ${ }^{12,40}$ The $\mathrm{R} 2$ range was found to be between 0.67 and 0.91 , which indicates the presence of fecal contamination in the samples from $\mathrm{C} 2$ to $\mathrm{C} 10$, as also was suggested by the absolute concentrations and relative percentages of coprostanol shown in Table 2 . This can be justified by the fact that regions have a high population occupation, with intense waste disposal. Despite the high concentration of coprostanol found in the $\mathrm{C} 4$ sediment, the $\mathrm{R} 2$ ratio was the lowest found, which can be explained either by the in situ conversion of cholesterol to cholestanol or by the inputs of cholestanol coming from sewage discharge. ${ }^{5,20}$

The R3 (coprostanol + epicoprostanol / (coprostanol + epicoprostanol + cholestanol)) can be a complementary of $\mathrm{R} 2$ ratio and it is used to compensate any microbial conversion of coprostanol into its diastereoisomer, epicoprostanol. The R3 ratio is used as an indicator of sewage contamination for values above 0.7 , while values less than 0.3 indicate uncontaminated environments. ${ }^{7,9,13}$ The values varied from 0.71 to 0.91 , which suggests the presence of sewage in all sediments from C2 to C10, converging with the result obtained in $\mathrm{R} 1$ and $\mathrm{R} 2$ ratios, which provides greater reliability for the indication of high contamination in these sediments.

The coprostanol/cholesterol and coprostanol/ cholestanol ratios (R4 and $\mathrm{R} 5$, respectively) are often used to distinguish between biogenic and anthropogenic sources of OM. For both ratios, values higher than 0.2 are indicative of contamination by sewage. ${ }^{8}$ The $\mathrm{R} 4$ ratio varied between 3.05 and 8.31 while R5 varied between 2.03 and 9.72 . Thus, for both ratios this study verified that the sources of contamination are anthropogenic (sewage input), which also corroborates the results obtained for $\mathrm{R} 1, \mathrm{R} 2$ and $\mathrm{R} 3$ ratios.

The R6 ratio (epicoprostanol/coprostanol) was used to assess a possible treatment of the effluent, considering that epicoprostanol comes from aerobic digestion of wastewater treatment plants. Values below 0.2 indicate that the environment was contaminated by untreated domestic sewage; values above 0.8 indicate no contamination or prevalence of treated sewage; and values between 0.2 and 0.8 are considered inconclusive. ${ }^{12,13,40}$ The range was found to be between 0.05 and 0.2 , which indicates that all sediment samples were contaminated by untreated sewage. Note that the high concentration of coprostanol found in $\mathrm{C} 4\left(557.3 \mu \mathrm{g} \mathrm{g}^{-1}\right)$ results in a high conversion to epicoprostanol $^{12}\left(125.1 \mu \mathrm{g} \mathrm{g}^{-1}\right)$ which gave it the highest values found for the R6 ratio (0.2) among the samples. 
The sterol ratios showed that untreated sewage is a relevant source of OM in sediments from the Ipojuca River (except for $\mathrm{C} 1$ ). An observation must be given in relation to the $\mathrm{C} 4$ sediment: although it does not have the highest diagnostic ratios, it should still be identified as the most contaminated sediment due to the highest concentration of coprostanol and OM, TOC, TN and TOC/TN.

\section{Principal component analysis}

A principal component analysis (PCA) was used to assess contamination levels and differentiate the $\mathrm{OM}$ sources: the greater the distance between them, the greater the differences. ${ }^{16,36}$ Figure 2 displays a pair of charts that shows the relationship between the scores (Figure 2a) and loadings (Figure 2b), and associates the results with sampling stations. The first two principal components explained $57.49 \%$ (PC1) and $21.60 \%$ (PC2) of the data variation, with a total cumulative variation of $79.09 \%$.

The PCA clearly shows that $\mathrm{C} 1$ and $\mathrm{C} 4$ are very different from the other samples. For $\mathrm{C} 1$, this distinction occurs due to
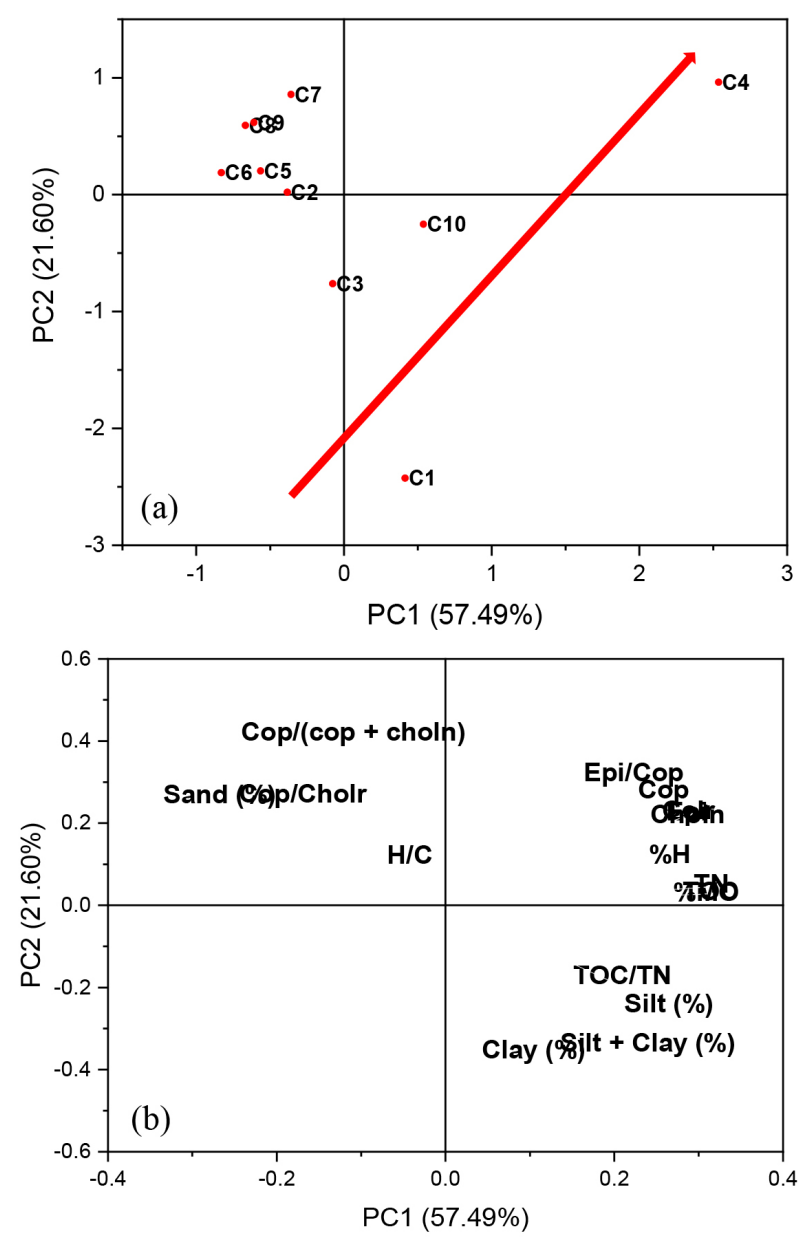

Figure 2. Charts of scores (a) and loadings (b) obtained of results of the sediment samples from Ipojuca River, Pernambuco, Brazil. the concentration of coprostanol, epicoprostanol, cholesterol, cholestanol and their diagnostic ratios, which were below the limit of quantification or could not be calculated. On the other hand, the $\mathrm{C} 4$ sample was distinguished by having the highest values obtained for fecal biomarkers (coprostanol and epicoprostanol), cholesterol and cholestanol, diagnostic ratio epicoprostanol/coprostanol and some classical analyses (TOC, TN, TOC/TN and OM).

A cluster formed by $\mathrm{C} 2, \mathrm{C} 5, \mathrm{C} 6, \mathrm{C} 7, \mathrm{C} 8$ and $\mathrm{C} 9$ samples is positively correlated to the group formed by fecal diagnostic ratios, $\mathrm{H} / \mathrm{C}$ and \%sand, as they have the highest values of these variables. The PC1 of the score chart seems to differentiate the samples in terms of their granulometry, and their different associations indicate that does not influence on other results obtained for the classical and sterol analyses.

A statistical analysis by PCA based on the results of classical and sterol analyses reinforces the conclusion that the sediments from $\mathrm{C} 2$ to $\mathrm{C} 10$ had high levels of contamination, that can be differentiated from less contaminated sediment $(\mathrm{C} 1)$ to the most contaminated (C4), as indicated by the red arrow in Figure 2a.

\section{Hierarchical cluster analysis/heatmap}

The HCA/heatmap built for variables and sediments collected in the Ipojuca River (Figure 3) allowed us to observe which variables have the greatest influence on the

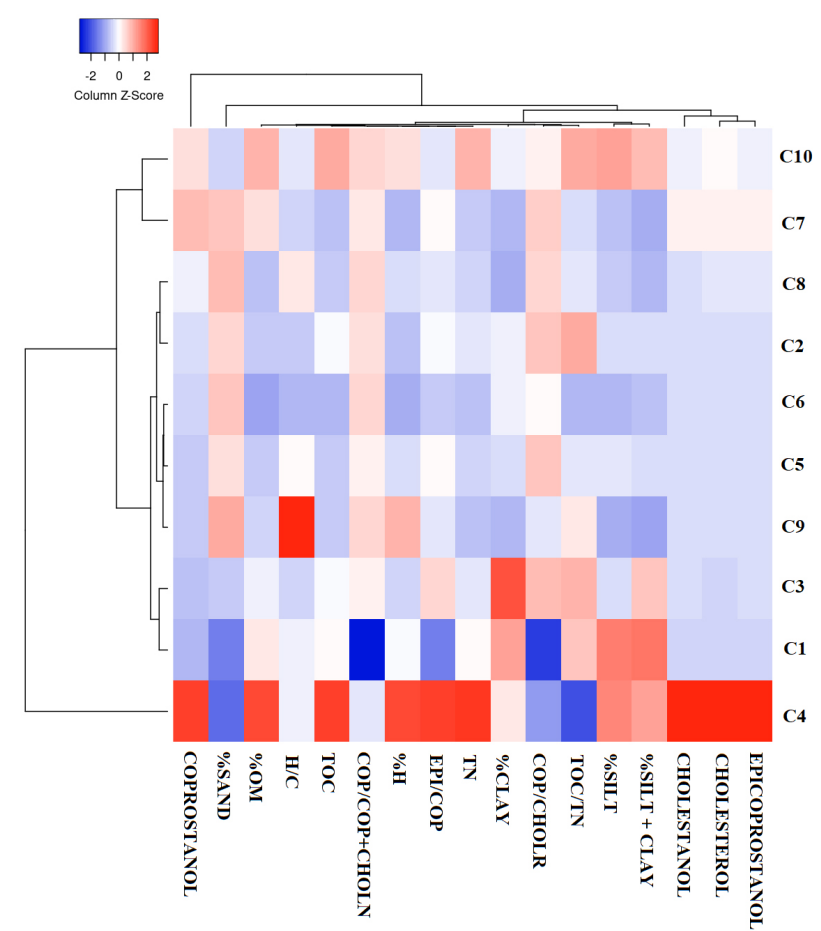

Figure 3. HCA/heatmap of the data from classical and sterol analyses of surface sediments from Ipojuca River. 
samples through shading of reddish tones (redder indicates greater weight).

It is still possible to note a distinction between $\mathrm{C} 4$ and the other samples through the reddish tones due to the high values of biomarkers as coprostanol, cholesterol, cholestanol and epicoprostanol, as well as the variables: silt, clay, OM, TOC and TN. Reddish tones can also be seen in samples from $\mathrm{C} 2$ to $\mathrm{C} 10$ (except $\mathrm{C} 4$ sample) due to high values for ratio coprostanol/(coprostanol + cholestanol) and coprostanol/cholesterol. Despite having high coprostanol concentrations, the values of these ratios obtained for the $\mathrm{C} 4$ sediment causes samples to show colder tones for the ratio coprostanol/(coprostanol + cholestanol) and coprostanol/ cholesterol. C1 sediment is also distinguished with cold tones due to the low values of the biomarkers and their diagnostic ratios, as previously discussed.

Thus, the HCA/heatmap analysis agrees with the PCA data presented in Figure 2, where all samples (except C1) are indicated as highly contaminated by sewage, with $\mathrm{C} 4$ as the most critical point.

\section{Conclusions}

The study was able to reveal the main sources of $\mathrm{OM}$ and the level of sewage contamination for the surface sediments of the Ipojuca River, Pernambuco, Brazil. Classical analyses suggested that the region is subject to aquatic OM (autochthonous) and the absolute concentrations of sterols, relative percentages of coprostanol and diagnostic sterol ratios indicate that urban sewage is the main source of OM in $90 \%$ of the sediments. The multivariate data analysis (PCA and HCA/ heatmap) gave a clear way of level of contamination for the samples, which indicated that the $\mathrm{C} 4$ sediment sample was the most critical in terms of sewage contamination due to its location close of the open-market of Caruaru city, in a region of high population occupation. Thus, the results and discussion presented here reveals the necessity of application of remediation strategies policies to preserve this aquatic environment.

\section{Supplementary Information}

Supplementary information about the analytical parameters for detection and quantification of sterols in sediment samples by LC-MS/MS described by Bataglion et al. ${ }^{8}$ and infrared spectrum of sediments samples collected in the Ipojuca River, Pernambuco, Brazil are available free of charge at http://jbcs.sbq.org. br as PDF file.

\section{Acknowledgments}

This study was funded by Fundação de Amparo a Ciência e Tecnologia do Estado de Pernambuco (FACEPE). The authors would like to thank the multi-user analytical laboratories CLQM/UFS and LABMAQ/UFRPE. G. A. B. would like to thank Universidade Federal do Amazonas (UFAM), Conselho Nacional de Desenvolvimento Científico e Tecnológico (CNPq, Brazil), Coordenação de Aperfeiçoamento de Pessoal de Nível Superior (CAPES, Brazil, finance code 001) and Fundação de Amparo à Pesquisa do Estado do Amazonas (FAPEAM, Brazil) for financially support part of this study.

\section{Author Contributions}

Ana Flávia B. de Oliveira was responsible for writing and organization of the article, analysis, interpretation of the results, statistical analysis, writing review and editing; Bruna R. S. Gomes for methodology and interpretation of the results; Rebeca S. França for methodology, validation, investigation; Alex S. Moraes contributed to the interpretation of the results; Giovana A. Bataglion for methodology, validation, investigation, writing review and editing; Jandyson M. Santos was project coordinator, contributed with analysis tools, interpretation of the results, critical revision of the manuscript.

\section{References}

1. Vane, C. H.; Kim, A. W.; McGowan, S.; Leng, M. J.; Heaton, T. H. E.; Kendrick, C. P.; Coombs, P.; Yang, H.; Swann, G. E. A.; Sci. Total Environ. 2010, 409, 345.

2. Sistema Nacional de Informações sobre Saneamento (SNIS); $24^{\circ}$ Diagnóstico dos Serviços de Água e Esgotos, Ministério do Desenvolvimento Regional, Secretaria Nacional de Saneamento: Brasília, 2019, available at http://www.snis.gov. br/downloads/diagnosticos/ae/2018/Diagnostico_AE2018.pdf, accessed in September 2021.

3. Frena, M.; Santos, A. P. S.; Souza, M. R. R.; Carvalho, S. S.; Madureira, L. A. S.; Alexandre, M. R.; Mar. Pollut. Bull. 2019, 139, 111.

4. Huguet, A.; Vacher, L.; Saubusse, S.; Etcheber, H.; Abril, G.; Relexans, S.; Ibalot, F.; Parlanti, E.; Org. Geochem. 2010, 41, 595.

5. Martins, C. C.; Cabral, A. C.; Barbosa-Cintra, S. C. T.; Dauner, A. L. L.; Souza, F. M.; Environ. Pollut. 2014, 188, 71.

6. Frena, M.; Souza, M. R. R.; Damasceno, F. C.; Madureira, L. A. S.; Alexandre, M. R.; Mar. Pollut. Bull. 2016, 109, 619.

7. Tse, T. J.; Codling, G.; Jones, P. D.; Thoms, K.; Liber, K.; Giesy, J. P.; Wheater, H.; Doig, L. E.; Chemosphere 2014, 103, 299.

8. Bataglion, G. A.; Meurer, E.; de Albergaria-Barbosa, A. C. R.; Bícego, M. C.; Weber, R. R.; Eberlin, M. N.; Anal. Chem. 2015, 87,7771 . 
9. He, D.; Zhang, K.; Tang, J.; Cui, X.; Sun, Y.; Sci. Total Environ. 2018, 636, 787 .

10. Souza, M. R. R.; Santos, E.; Suzarte, J. S.; do Carmo, L. O.; Soares, L. S.; Santos, L. G. G. V.; Júnior, A. R. V.; Krause, L. C.; Frena, M.; Damasceno, F. C.; Huang, Y.; Alexandre, M. R.; Mar. Pollut. Bull. 2020, 154, 111067.

11. Carreira, R. S.; Araújo, M. P.; Costa, T. L. F.; Spörl, G.; Knoppers, B. A.; Mar. Chem. 2011, 127, 1.

12. Martins, C. C.; Gomes, F. B. A.; Ferreira, J. A.; Montone, R. C.; Quim. Nova 2008, 31, 1008.

13. Matić Bujagić, I.; Grujić, S.; Jauković, Z.; Laušević, M.; Environ. Pollut. 2016, 213, 76.

14. Bataglion, G. A.; Koolen, H. H. F.; Weber, R. R.; Eberlin, M. N.; Int. J. Anal. Chem. 2016, ID 8361375.

15. Tolosa, I.; Mesa, M.; Alonso-Hernandez, C. M.; Mar. Pollut. Bull. 2014, 86, 84 .

16. Derrien, M.; Jardé, E.; Gruau, G.; Pourcher, A. M.; Gourmelon, M.; Jadas-Hécart, A.; Wickmann, A. C. P.; Water Res. 2012, 46, 4009.

17. Gomes, H. G.; Kawakami, S. K.; Taniguchi, S.; Souza Filho, P. W.; Montone, R. C.; Braz. J. Oceanogr. 2015, 63, 501.

18. de Aquino Neto, F. R.; Nunes, D. S. S.; CromatografiaPrincípios Básicos e Técnicas Afins; Interciência: Rio de Janeiro, 2003.

19. Plano Hidroambiental da Bacia Hidrográfica do Rio Ipojuca; Governo do Estado de Pernambuco Secretaria de Recursos Hídricos: Recife-PE, 2010, available at www.sirh.srh.pe.gov. br/hidroambiental/files/ipojuca/TOMO V- Mapas correto.pdf, accessed in September 2021.

20. de Melo, M. G.; da Silva, B. A.; Costa, G. S.; da Silva Neto, J. C. A.; Soares, P. K.; Val, A. L.; Chaar, J. S.; Koolen, H. H. F.; Bataglion, G. A.; Environ. Pollut. 2019, 244, 818.

21. Rosa, A. H.; Rocha, J. C.; Furlan, M.; Quim. Nova 2000, 23, 472.

22. Suguio, K.; Introdução à Sedimentologia; Edgard Buckler, EDUSP: São Paulo, 1973.

23. Rau, M.; Bataglion, G. A.; Madureira, L. A. D. S.; Rev. Virtual Quim. 2013, 5, 201.

24. Dias, B. D. O.; Silva, C. A.; Mercês, E.; Rev. Bras. Cienc. Solo 2009, 33, 885 .

25. Wang, L.; Cheng, Y.; Lamb, D.; Dharmarajan, R.; Chadalavada, S.; Naidu, R.; Spectrochim. Acta, Part A 2019, 207, 183.
26. Veerasingam, S.; Venkatachalapathy, R.; Infrared Phys. Technol. 2014, 66, 136.

27. Gomes, A. O.; Azevedo, D. A.; J. Braz. Chem. Soc. 2003, 14, 358.

28. Mayer, L. M.; Geochim. Cosmochim. Acta 1994, 58, 1271.

29. Frena, M.; Bataglion, G. A.; Sandini, S. S.; Kuroshima, K. N.; Eberlin, M. N.; Madureira, L. A. S.; J. Braz. Chem. Soc. 2017, 28, 603 .

30. Meyers, P. A.; Org. Geochem. 2003, 34, 261.

31. Santos, J. M.; dos Santos, L. O.; Costa, J. A. S.; Menezes, L. C. S.; Holanda, F. S. R.; Bellin, I. C.; Rev. Virtual Quim. 2015, 7, 2139.

32. Meyers, P. A.; Org. Geochem. 1997, 27, 213.

33. Jeng, W. L.; Han, B. C.; Estuarine, Coastal Shelf Sci. 1996, 42, 727.

34. Grilo, C. F.; Neto, R. R.; Vicente, M. A.; de Castro, E. V. R.; Figueira, R. C. L.; Carreira, R. S.; Appl. Geochem. 2013, 38, 82.

35. Lima, E. A. M.: Avaliação da Qualidade dos Sedimentos e Prognóstico Geoquímico Ambiental da Zona Estuarina do Rio Botafogo, Pernambuco; PhD Thesis, Universidade Federal de Pernambuco, Recife, Brazil, 2008, available at https://rigeo. cprm.gov.br/xmlui/handle/doc/272, accessed in September 2021.

36. Speranza, E. D.; Colombo, M.; Skorupka, C. N.; Colombo, J. C.; Org. Geochem. 2018, 117, 1.

37. Arcega-Cabrera, F.; Velázquez-Tavera, N.; Fargher, L.; Derrien, M.; Noreña-Barroso, E.; J. Contam. Hydrol. 2014, 168, 41.

38. Puerari, L.; Carreira, R. S.; Neto, A. C. B.; Albarello, L. C.; Gallotta, F. D. C.; J. Braz. Chem. Soc. 2012, 23, 2027.

39. Venkatesan, M. I.; Merino, O.; Baek, J.; Northrup, T.; Sheng, Y.; Shisko, J.; Mar. Environ. Res. 2010, 69, 350.

40. Hadlich, H. L.; Venturini, N.; Martins, C. C.; Hatje, V.; Tinelli, P.; Gomes, L. E. O.; Bernardino, A. F.; Ecol. Indic. 2018, 95, 21.

41. Frena, M.; Bataglion, G. A.; Tonietto, A. E.; Eberlin, M. N.; Alexandre, M. R.; Madureira, L. A. S.; Sci. Total Environ. 2016, 544,432

Submitted: June 24, 2021

Published online: September 23, 2021 